\title{
Gambaran Indeks Eritrosit Rerata pada Laki-laki Dewasa dengan Diabetes Melitus Tipe 2
}

\author{
${ }^{1}$ Talitha D. Saraswati \\ ${ }^{2}$ Linda W. A. Rotty \\ ${ }^{3}$ Karel Pandelaki
}

\author{
${ }^{1}$ Program Studi Pendidikan Dokter Fakultas Kedokteran Universitas Sam Ratulangi Manado \\ ${ }^{2}$ Bagian Ilmu Penyakit Dalam Fakultas Kedokteran Universitas Sam Ratulangi Manado \\ Email: talithasaraswatii@gmail.com
}

\begin{abstract}
Diabetes mellitus (DM) is a metabolic disease indicated by high level of blood sugar resulting from a defect in insulin secretion, insulin activity, or both. The prevalence of DM in Indonesia is $1.9 \%$, making it the 7th leading cause of deaths worldwide. In diabetic patients it is common to find any disorder in several systems, inter alia disorder of erythrocytes. An important indicator in portraying the erythrocytes state is the average erythrocyte indices ( $\mathrm{MCV}, \mathrm{MCH}$, and $\mathrm{MCHC})$. This study was aimed to provide an overview of the average erythrocyte indices in young adult males with type 2 DM (T2DM) at the Endocrine Polyclinic of Prof. Dr. R. D. Kandou Hospital. This was a descriptive and retrospective study using medical records of diabetic patients at the Endocrine Policlinic from September 2018 to September 2019. The results obtained a total of 1.432 medical records consisting of 550 males and 882 females. However, only 22 samples met the inclusion criteria, with a majority of samples were 40 to 45 years old (50\%). Generally, the erythrocyte indices were still in normal range. Albeit, a few samples showed a decrease in hemoglobin level, $\mathrm{MCV}$, and $\mathrm{MCH}$. In conclusion, there was no significant change in the erythrocyte indices among adult males with type 2 diabetes mellitus at the Endocrine Polyclinic of Prof. Dr. R. D. Kandou Hospital.
\end{abstract}

Keywords: average erythrocyte indices, type 2 diabetes mellitus

\begin{abstract}
Abstrak: Diabetes melitus (DM) merupakan penyakit metabolik yang ditandai dengan tingginya kadar gula darah akibat defek sekresi insulin, kerja insulin, atau keduanya. Prevalensi DM di Indonesia sebesar 1,9\% menjadikan DM sebagai penyebab kematian urutan ke tujuh di dunia. Pada pasien DM seringkali ditemukan gangguan pada berbagai sistem, salah satunya pada eritrosit. Indikator penting yang dapat mencerminkan keadaan eritrosit ialah indeks eritrosit rerata (MCV, MCH, dan MCHC). Penelitian ini bertujuan untuk mengetahui gambaran indeks eritrosit rerata pada pasien laki-laki dewasa penyandang DM tipe 2 di Poliklinik Endokrin RSUP Prof. Dr. R. D. Kandou. Jenis penelitian ialah deskriptif retrospektif menggunakan data rekam medik pasien di Poli Endokrin RSUP Prof. Dr. R. D. Kandou periode September 2018 hingga September 2019. Hasil penelitian mendapatkan 1.432 rekam medis, terdiri dari 550 laki-laki dan 882 perempuan, namun hanya 22 data yang memenuhi kriteria penelitian, dengan mayoritas berusia 40-45 tahun (50\%). Secara umum nilai indeks eritrosit rerata masih dalam rentang normal, namun terdapat beberapa sampel dengan penurunan kadar hemoglobin, MCV, dan $\mathrm{MCH}$. Simpulan penelitian ini ialah tidak terdapat gambaran bermakna pada indeks eritosit pasien laki-laki dewasa dengan DM tipe 2 di Poliklinik Endokrin RSUP Prof. Dr. R. D. Kandou
\end{abstract}

Kata kunci: indeks eritrosit rerata, diabetes melitus tipe 2 
Diabetes melitus (DM) merupakan penyakit metabolik yang ditandai dengan tingginya kadar gula darah akibat defek sekresi insulin, kerja insulin, atau keduanya. ${ }^{1}$ Prevalensi penyakit ini telah meningkat lebih dari $50 \%$ dan saat ini disandang oleh 400 juta orang di seluruh dunia. ${ }^{2}$ Diabetes melitus tipe 2 (DMT2) secara global telah disandang $18-20 \%$ orang dewasa di atas usia 65 tahun dan diperkirakan sekitar 285 juta orang yang berusia antara 20 hingga 79 tahun. Sebanyak $70 \%$ di antaranya tinggal di negara berpenghasilan rendah hingga menengah. Jumlah ini akan terus meningkat sebanyak $50 \%$ selama 20 tahun ke depan jika program pencegahan tidak dilaksanakan. Pada tahun 2030, diperkirakan hampir 438 juta orang, 8\% dari populasi orang dewasa, akan menyandang DM di dunia. ${ }^{1}$

World Health Association (WHO) memrediksi jumlah penyandang DM di Indonesia akan mengalami peningkatan dari 8,4 juta pada tahun 2000 menjadi 21,3 juta pada tahun $2030 .^{3}$ International Diabetes Federation (IDF) menyebutkan bahwa akan terjadi peningkatan jumlah penyandang DM di Indonesia pada tahun 2013 dari 8,5 juta menjadi 14,1 juta pada tahun 2035. ${ }^{4}$ Menurut hasil Riset Kesehatan Dasar (Riskesdas) 2018, terdapat peningkatan jumlah penyandang DM pada tahun 2013-2018..$^{5}$ Pada penelitian bulan Mei hingga Oktober 2011 didapatkan pasien DMT2 baru sebanyak 138 pasien yang terdiri dari 60 laki-laki (43\%) dan 78 perempuan $(57 \%)$ di Poliklinik Endokrin dan Metabolik RSUP Prof. Dr. R. D. Kandou Manado. ${ }^{6}$

Pada pasien DM seringkali ditemukan gangguan pada berbagai sistem, salah satunya gangguan pada eritrosit. Indeks eritrosit rerata terdiri atas mean corpuscular volume (MCV), mean corpuscular haemoglobin $(\mathrm{MCH})$, dan mean corpuscular haemoglobin concentration (MCHC) yang merupakan indikator penting untuk mencerminkan keadaan eritrosit. Pemeriksaan indeks eritrosit rerata biasanya digunakan untuk melihat jenis anemia. Indeks eritrosit rerata dapat dihitung jika nilai haemoglobin $(\mathrm{Hb})$, hematokrit, dan jumlah eritrosit diketahui. ${ }^{7}$

Sehubungan dengan peningkatan tingkat penyandang DM di Sulawesi Utara dan adanya temuan hubungan DM dengan indeks eritrosit rerata, maka peneliti tertarik untuk mengetahui gambaran indeks eritrosit rerata pada pasien DMT2 laki-laki dewasa di poli endokrin RSUP Prof. Dr. R. D. Kandou Manado. Diharapkan dengan mengetahui gambaran indeks eritrosit rerata pada pasien DMT2, dapat dilakukan tindak lanjut sehingga komplikasi dapat dihindari.

\section{METODE PENELITIAN}

Penelitian ini menggunakan data rekam medik pasien DMT2 di Poli Endokrin yang dirawat di RSUP Prof. Dr. R. D. Kandou periode September 2018 hingga September 2019 dengan rentang usia 26-45 tahun tanpa komplikasi ginjal. Jenis penelitian ini ialah deskriptif retrospektif dengan desain potong lintang.

\section{HASIL PENELITIAN}

Hasil penelitian menggunakan data rekam medik pasien laki-laki dewasa DMT2 di Poliklinik Endokrin RSUP Prof. Dr. R. D. Kandou dari September 2018 hingga September 2019. Total data rekam medis yang didapatkan yaitu 1.432 rekam medis, terdiri dari 550 laki-laki dan 882 perempuan, tetapi hanya 22 rekam medis yang memenuhi kriteria penelitian.

Tabel 1 memperlihatkan bahwa sebagian besar pasien berusia 40-45 tahun yaitu 11 orang $(50 \%)$, dan yang paling sedikit ialah berusia 30-34 tahun dan berusia 3539 tahun, masing-masing berjumlah 3 orang $(13,6 \%)$.

Tabel 1. Distribusi pasien laki-laki dewasa berdasarkan usia

\begin{tabular}{ccc}
\hline $\begin{array}{c}\text { Usia } \\
\text { (tahun) }\end{array}$ & $\mathbf{N}$ & $\begin{array}{c}\text { Persentase } \\
(\mathbf{\%})\end{array}$ \\
\hline $25-29$ & 5 & 22,7 \\
$30-34$ & 3 & 13,6 \\
$35-39$ & 3 & 13,6 \\
$40-45$ & 11 & 50 \\
Jumlah & 22 & 100 \\
\hline
\end{tabular}


Tabel 2. Karakteristik sampel penelitian

\begin{tabular}{cccccc}
\hline & N & Minimum & Maksimum & Mean & $\begin{array}{c}\text { Std. } \\
\text { Deviation }\end{array}$ \\
\hline $\mathrm{Hb}(\mathrm{g} / \mathrm{dl})$ & 22 & 8,3 & 17,7 & 13,5 & 2,5 \\
$\mathrm{MCV}(\mathrm{fL})$ & 22 & 78,1 & 100 & 83,3 & 6,1 \\
$\mathrm{MCH}(\mathrm{pg})$ & 22 & 21,6 & 36,8 & 28,2 & 2,7 \\
$\mathrm{MCHC}(\mathrm{g} / \mathrm{dl})$ & 22 & 32,1 & 36,8 & 34 & 1,8 \\
$\mathrm{HbA} 1 \mathrm{c}(\%)$ & 22 & 5,2 & 14,4 & 10,2 & 2,4 \\
Kreatinin (mg/dl) & 22 & 0,3 & 1,3 & 0,8 & 0,2 \\
\hline
\end{tabular}

Tabel 2 memperlihatkan nilai terendah, nilai tertinggi, nilai rerata, dan nilai simpang baku dari hemoglobin $(\mathrm{Hb}), \mathrm{MCV}, \mathrm{MCH}$, MCHC, HbAlc, dan kreatinin. Secara umum, nilai-nilai tersebut masih berada dalam rentang normal.

\section{BAHASAN}

Hasil penelitian menunjukkan bahwa pasien laki-laki dewasa dengan DMT2 paling banyak berada pada rentang usia 4045 tahun yang berjumlah 11 orang $(50 \%)$ dan yang paling sedikit terdapat pada rentang usia 30-34 tahun dan 35-39 tahun yang keduanya berjumlah sebanyak 3 orang $(13,6 \%)$ (Tabel 1).

Gambaran $\mathrm{Hb}$ masih dikategorikan normal (nilai rerata $13,5 \mathrm{~g} / \mathrm{dl}$ ), dimana rentang nilai normal $\mathrm{Hb}$ pada laki-laki ialah 13,5-17,5 g/dl. Gambaran MCV masih dalam kategori normal (nilai rerata 83,3 fL), dengan rentang normal 81-96 fL. Gambaran $\mathrm{MCH}$ masih dalam kategori normal (nilai rerata 28,2 pg) dengan rentang normal 27-31 pg. Gambaran MCHC masih dalam kategori normal (nilai rerata $34 \mathrm{~g} / \mathrm{dl}$ ) dengan rentang normal 30-36 g/dl. Gambaran $\mathrm{HbA1c}$ rerata $10,2 \%$ menunjukkan bahwa sebagian besar pasien tidak memiliki gula darah terkontrol dimana batas normal HbA1c ialah $\leq 7 \%$. Nilai kreatinin rerata $0,8 \mathrm{mg} / \mathrm{dl}$ menunjukkan bahwa pasien tidak memiliki gangguan ginjal, dimana nilai batas normal kreatinin ialah $<1,3 \mathrm{mg} / \mathrm{dl}$ (Tabel 2).

Hasil penelitian ini menunjukkan bahwa tidak terdapat gambaran bermakna pada $\mathrm{Hb}$ dan indeks eritosit (MCV, $\mathrm{MCH}$, MCHC) pasien laki-laki dewasa usia 25-45 tahun dengan DMT2. Secara umum nilai indeks eritrosit rerata masih dalam rentang normal. Terdapat data yang memperlihatkan penurunan kadar $\mathrm{Hb}, \mathrm{MCV}$, dan MCH pada beberapa pasien; hal ini mungkin disebabkan oleh factor lainnya. Faktor-faktor yang dapat memengaruhi indeks eritrosit rerata dan $\mathrm{HbA} 1 \mathrm{c}$ yaitu usia yang lebih tua, peradangan kronis, dan juga kondisi yang dapat memengaruhi kelangsungan hidup eritrosit seperti transfusi darah, kehilangan darah, dan penyakit ginjal. ${ }^{8}$ Anemia pada pasien DM tidak terkait secara langsung namun komplikasi diabetes atau penyakit tertentu dapat menyebabkan anemia. ${ }^{9}$

Penelitian yang dilakukan oleh Bhutto et al $^{10}$ pada 119 pasien mendukung hasil penelitian ini yaitu didapatkan $\mathrm{MCV}$, $\mathrm{MCH}$, dan $\mathrm{MCHC}$ yang tidak berkorelasi dengan peningkatan $\mathrm{HbA1c}$. Belum terjadinya perubahan diperkirakan karena durasi pasien mengalami DM yang belum lama. Jumlah eritrosit pada pasien yang lebih tua, terutama laki-laki dengan durasi diabetes yang lama dilaporkan mengalami penurunan akibat komplikasi DM. Penurunan ini terjadi akibat defisiensi eritropoeietin atau akibat peningkatan kerusakan eritrosit sekunder oleh perubahan struktur sel. ${ }^{9}$

Hasil penelitian yang dilakukan oleh Jaman et $\mathrm{al}^{11}$ pada 87 orang pasien laki-laki dan perempuan DMT2 berusia 25-80 tahun mendapatkan penurunan nilai $\mathrm{MCV}$ serta peningkatan MHC dan MCHC dengan diikuti peningkatan nilai $\mathrm{HbA1c}$. Walaupun hasil penelitian ini dan penelitian oleh Jaman et $\mathrm{al}^{11}$ mendapatkan kadar HbA1c yang tinggi tetapi pada penelitian ini 
digunakan sampel dan kriteria yang berbeda, yaitu sampel dipilih hanya pada rentang usia 25-45 tahun, jenis kelamin hanya laki-laki, fungsi ginjal dalam kisaran normal, dan tidak memiliki komplikasi penyakit lain.

Terdapat beberapa hal yang dapat menimbulkan perbedaan hasil penelitian seperti subjek penelitian, usia, jenis kelamin, banyaknya sampel penelitian, lama periode penelitian, dan komplikasi penyakit penyerta.

\section{SIMPULAN}

Berdasarkan hasil penelitian ini dapat disimpulkan bahwa tidak terdapat gambaran bermakna dari rerata $\mathrm{MCV}, \mathrm{MCH}$, dan MCHC pada pasien laki-laki dewasa penyandang DMT2 di Poliklinik Endokrin RSUP Prof. Dr. R. D. Kandou dari September 2018 hingga September 2019.

Pada penelitian selanjutnya diharapkan dapat dilakukan terhadap pasien DMT2 baru dengan menggunakan data primer agar data yang didapatkan lebih banyak dan lengkap dengan tetap memperhatikan riwayat pengobatan, riwayat penyakit, dan komplikasi lainnya.

\section{DAFTAR PUSTAKA}

1. American Diabetes Association. Diagnosis and classification of diabetes mellitus. Diabetes Care. 2014;37(Suppl 1):S81S90.

2. Fatimah NR. Diabetes Melitus Tipe 2. J Majority. 2015;4:94.

3. PERKENI. Konsensus Pengelolaan dan Pencegahan Diabetes Melitus Tipe 2 di Indonesia 2011. Jakarta: PERKENI, 2011.

4. International Diabetes Federation. IDF
Diabetes Atlas (7th ed). 2015. Accessed on 4 January 2017.

5. Suyono S, editor. Diabetes Melitus Indonesia.. Buku Ajar Ilmu Penyakit Dalam (6th ed). Jakarta: Interna Publishing, 2014; p. 2320.

6. Awad N, Langi JA, Pandelaki K. Gambaran faktor resiko pasien diabetes melitus tipe II di Poliklinik Endokrin Bagian/SMF FK-Unsrat RSUP Prof. Dr. R. D. Kandou Manado periode Mei-Oktober 2011. eBiomedik. 2013; 1(1):47-8.

7. Sarma PR. Red cell indices. In: Walker HK, Hall WD, Hurst JW, editors. Clinical Methods: The History, Physical, and Laboratory Examinations (3rd ed). Boston: Butterworths, 1990.

8. Oda E. Bilirubin is negatively associated with A1C independently of fasting plasma glucose, age, obesity, inflammation, hemoglobin, and iron in apparently healthy Japanese men and women. Diabetes Care. 2010;33:131.

9. Kimura T, Kaneto H, Kanda-Kimura Y, Shimoda M, Kamei S, Anno T, et al. Seven-year observational study on the association between glycemic control and the new onset of macroangiopathy in Japanese subjects with type 2 diabetes. Internal Medicine. 2016;55: 419-24.

10. Bhutto A, Abbasi A, Abro A. Correlation of hemoglobin A1c with red cell width distribution and other parameters of red blood cells in type II diabetes mellitus. Cureus. 11(8): e5533. doi:10.7759/ cureus.5533.

11. Jaman S, Rahman S, Swarna RR, Mahato J, Siddique AI, Miah M, et al. Diabetes and red blood cell parameters. Ann Clin Endocrinol Metabol. 2012; 35:64-71. 